\title{
Growth Performance of One Year Old Seedlings of Ironwood (Eusideroxylon zwageri Teijsm. \& Binn.) Varieties
}

\author{
Bambang Irawan \\ Department of Forestry, Faculty of Agriculture, Jambi University \\ Campus Pinang Masak, Jambi-Muara Main Road, Bulian KM. 15 Mendalo Darat-Jambi 36361 Indonesia
}

Received March 5, 2012/Accepted July 30, 2012

\begin{abstract}
Four Eusideroxylon zwageri Teijsm. \& Binn. varieties had been described. A study on growth performance of oneyear old seedlings of E. zwageri varieties had been conducted to study the comparison of shoot growth performance and survival among E. zwageri varieties. The varieties were exilis, grandis, ovoidus, and zwageri. The study was conducted in Jambi, Indonesia for one year using complete randomized design. Four E. zwageri varieties were used as factor with six replications. Each consists of six seedlings therefore, the total number of seedlings were 144. The results showed that survival and shoot growth performance of E. zwageri seedlings were significantly different among varieties. Stem height of E. zwageri seedlings was significantly different among some varieties. The results related to stem diameter showed different characteristics among E. zwageri seedlings, zwageri variety had the biggest diameter. It was significantly different from ovoidus and exilis, but not significantly different from grandis. The differences among E. zwageri seedlings in shoot dry weight parameter were identical to the parameter of stem diameter. The lowest value of branch angle belonged to zwageri. Based on Duncan multiple range test, it was significantly different from other varieties except grandis. Generally, zwageri shows the best growth performance among seedlings of E. zwageri varieties.
\end{abstract}

Keywords: growth performance, ironwood, seedlings, varieties

*Correspondence author,email: irawanbam@yahoo.com,telp.+62-741-583111

\section{Introduction}

Borneo and Sumatera ironwood, locally called as bulian/ulin/belian/onglen (Eusideroxylon zwageri Teijsm. \& Binn.) belongs to the family of Lauraceae, tribus of cryptocaryeae and subtribus of Eusideroxylineae (Kostermans 1957). Ironwood is one of the most important construction wood in Indonesia. The wood is used for making furniture, window and door frames, harbors, heavy constructions, roofs, bridges, railway sleepers, marine pilling, boat constructions, fence posts, heavy duty industrial flooring, shingles, and vehicle body work. E. zwageri is a threatened tree species which can be found naturally in some of Jambi forests. However, due to overexploitation and slow growing, its population is decreasing drastically.

Oldfield et al. (1998) showed that E. zwageri is included in the list of threatened tree species. Its decline was first noted in 1955. Population reduction caused by over exploitation and shifting agriculture has been noted in the following regions: Kalimantan, Sumatera, Sabah, Sarawak, and the Philippines. Its natural regeneration in logged forests is limited. So far, the species has only been planted on a small scale because the supply of seeds and seedlings is inadequate.

E. zwageri's seeds have different shapes and sizes. They have been used as main characteristics to distinguish $E$. zwageri varieties. Grandis's seed is sub-cylindrical; exilis has slender seeds, ovoidus has rounded seeds while zwageri's seed is in between cylindrical and rounded. The leaf form of E. zwageri varieties varies. The forms of zwageri's leaves are oblong to elliptic; grandis's and exilis's leaves tend to obovate while ovoidus's leaves tend to ovate. The most different bark structure and color of $E$. zwageri belong to ovoidus variety. It is smooth and white to pale yellow color. Molecular genetic analysis proved that differentiation on morphological structures, which was revealed by the researches and recognized by local people, has a genetic basis (Irawan \& Gruber 2004; Irawan 2005).

E. zwageri is known as a very slow growing species, even under optimal conditions (Kostermans et al. 1994). In natural forests, E. zwageri will reach its mature size in 200 years or even more (Beekman 1949). Additionally, Ashton (1981) reported that the average girth increment of $E$. zwageri at all sizes was extremely low, about 0.3 inches $(8 \mathrm{~mm})$ per annum. Weidelt (1997) stated that for a medium size E. zwageri, the annual diameter increment is only $2-3 \mathrm{~mm}$; on a good site near a creek or river it may reach $4-5 \mathrm{~mm}$. Kurokawa et al. (2003) reported that the radial growth rate of E. zwageri estimated by ${ }^{14} \mathrm{C}$ dating was $0.058 \pm 0.025 \mathrm{~cm}_{\text {year }}{ }^{-1}$ with maximum and minimum of 0.136 and $0.025 \mathrm{~cm}^{\text {year }}{ }^{-1}$, respectively.

E. zwageri grows slowly when its stem diameter at breast height (dbh) is below $10 \mathrm{~cm}$. The growth markedly accelerates when the diameter at breast height ranges 
between 10 and $30 \mathrm{~cm}$. Growth is then reduced to a level intermediate between that of the former stages and remains steady until the diameter at breast height reaches $1 \mathrm{~m}$ or more. The time required for the E. zwageri stem to reach $30 \mathrm{~cm}$ in diameter at breast height is estimated at 120 year, and for $120 \mathrm{~cm}$ at 403 years (Kiyono \& Hastaniah 2000).

Tuyt (1939) reported that the height increment of $E$. zwageri in favorable environments is about $56 \mathrm{~cm}$ per year. The 17-year-old trees could reach $9.80 \mathrm{~m}$ in height. Mean annual diameter increment of young trees of E. zwageri may be $9.5 \mathrm{~mm}$ under good conditions, but usually it is less. Trees can reach a height of $8 \mathrm{~m}$ in 8 years and usually they are 9-14 $\mathrm{m}$ high after 16 years. The growth rate seems to be rather uniform during the life of a tree, but it will probably slow down slightly when the tree becomes older. The maximum diameter of 40-year-old trees is reportedly $36 \mathrm{~cm}$ and probably trees need over 100 years to reach a diameter of $50 \mathrm{~cm}$.

Early investigation and information from local people found that each variety has different growth performance. Exilis is believed to be the variety with the best growth performance. A study on growth performance of one-year old seedlings of $E$. zwageri varieties was conducted to find the comparison of shoot growth performance and seedlings survival among E. zwageri varieties and to find the variety with the best growth performance. This study is important to utilize the genetic potential especially on growth performance in early stage in order to shorten the time needed by $E$. zwageri to reach maturity. The objectives of the research are: 1) to study the growth performance and seedling survival among E. zwageri varieties and 2) to find the variety with the best growth performance.

\section{Methods}

The materials were E. zwageri seeds, soil, organic matter, sand, and nipa (Nipa fraticans) leaves. The research instruments were micrometer screw, GPS, Leaf area meter type CL-202, oven (Memmert), balances (Sartorius type 2842 and Oertling model OB152-CA4ZAA-A), pots, lumber, and stationery.

Seed collection The E. zwageri seeds were collected from the field during the field research at Senami forest, Jambi. The sample seeds were taken from Jambi Indonesia. Selected sample trees with the amount varied from 25-30 seeds per tree. The amount of seeds was 150 for each grandis and exilis variety and 200 seeds were collected for each ovoidus and zwageri variety. The distance between each mother tree varied from 500 meters to 1,500 meters.

Seed germination The germination was carried out using germination beds with the sand media. The size of the germination beds was $1.5 \times 2.5 \mathrm{~m}$. The seeds were inserted into the media with $5 \times 3 \mathrm{~cm}$ of spacing using complete randomized design. Thus, there were four varieties with six seeds/plot and six replications. The amount of seeds was 144 . The complete randomized design was chosen since the experiment was conducted in containers with relatively homogenous materials.

Nursery The seedlings were planted in pots containing a mixture of equal parts of topsoil, organic matter, and sand. The seedlings were put under two nipa shades with heights of $150 \mathrm{~cm}$ in the east part and $120 \mathrm{~cm}$ in the west. The size of each shade was $2 \times 7.5 \mathrm{~m}$ and the space between both shelters was $1.5 \mathrm{~m}$. The seedlings were watered twice daily to field capacity. Nursery tending was done according to the conditions of the seedlings and their environments. The pots were put in the same arrangement during germination but with different spacing. The space among pots in the same plot was $10 \mathrm{~cm}$ while the space between plots was $20 \mathrm{~cm}$.

Parameters and statistical analysis These parameters included: percentage of life seedlings $(\%)$, stem height $(\mathrm{cm})$, stem diameter $(\mathrm{cm})$, leaf area $\left(\mathrm{cm}^{2}\right)$, branch number and angle $\left({ }^{\circ}\right)$, root-collar diameter $(\mathrm{cm})$, length of taproot $(\mathrm{cm})$, number of secondary roots, shoot dry weight $(\mathrm{g})$, and root dry mass $(\mathrm{g})$. The data were subjected to statistical analysis: a one-way analysis of variance (Anova) with variety as a factor. The statistical test for all components of variance was determined at 0.05 significance level of Duncan multiple range test (Gomez \& Gomez 1984). The software package used to analyze data was Number Cruncher Statistical Systems (NCSS) (Hintze 2001).

\section{Results and Discussion}

The results of stem height and diameter measurements were shown in Figures 1 and Figure 2. Table 1 shows that all of the shoot traits and percentage of life seedlings of $E$. zwageri seedlings were significantly different among varieties. The percentage of life seedlings was accounted 1

Table 1 Mean values of percentage of life seedlings and shoot traits of four varieties of one year old Eusideroxylon zwageri Teijsm. \& Binn. seedlings

\begin{tabular}{lllclcc}
\hline \multicolumn{1}{c}{ Varie ties } & $\begin{array}{c}\text { Seedling survival } \\
(\%)\end{array}$ & $\begin{array}{c}\text { Stem height } \\
(\mathrm{cm})\end{array}$ & $\begin{array}{c}\text { Stem diameter } \\
(\mathrm{cm})\end{array}$ & $\begin{array}{c}\text { Shoot dry } \\
\text { weight }(\mathrm{g})\end{array}$ & $\begin{array}{c}\text { Branch angles } \\
\left({ }^{\circ}\right)\end{array}$ & $\begin{array}{c}\text { Amount of } \\
\text { branches }\end{array}$ \\
\hline Exilis & $72.22 \mathrm{a}$ & $54.167 \mathrm{ab}$ & $0.7350 \mathrm{a}$ & $17.010 \mathrm{a}$ & $30.00 \mathrm{~b}$ & $7.6 \mathrm{ab}$ \\
Ovoidus & $66.67 \mathrm{a}$ & $49.417 \mathrm{a}$ & $0.7704 \mathrm{a}$ & $16.013 \mathrm{a}$ & $25.00 \mathrm{~b}$ & $6.9 \mathrm{a}$ \\
Zwageri & $83.22 \mathrm{ab}$ & $62.883 \mathrm{~b}$ & $0.9354 \mathrm{~b}$ & $29.542 \mathrm{~b}$ & $13.33 \mathrm{a}$ & $9.0 \mathrm{~b}$ \\
Grandis & $91.50 \mathrm{~b}$ & $58.667 \mathrm{~b}$ & $0.8463 \mathrm{ab}$ & $22.985 \mathrm{ab}$ & $21.167 \mathrm{ab}$ & $6.8 \mathrm{a}$ \\
\hline
\end{tabular}

The mean values that are followed by the same letters are not significantly different based on $5 \%$ significance level of Duncan multiple range tests. 
year after sowing when they had been replanted to the field. The highest value of percentage of life seedlings belonged to grandis variety, this was significantly different from the percentage of life seedlings of ovoidus and exilis varieties.

Stem height of one-year E. zwageri seedlings was significantly different among some varieties. It was significantly different from grandis and zwageri variety, which had the highest stem height, while exilis, grandis, and zwageri varieties were not significantly from one another. The results related to stem diameter show different characteristics among E. zwageri seedlings. Zwageri had the biggest diameter. It was significantly different from ovoidus and exilis but not significantly different from grandis variety. However, grandis, ovoidus, and exilis varieties were not

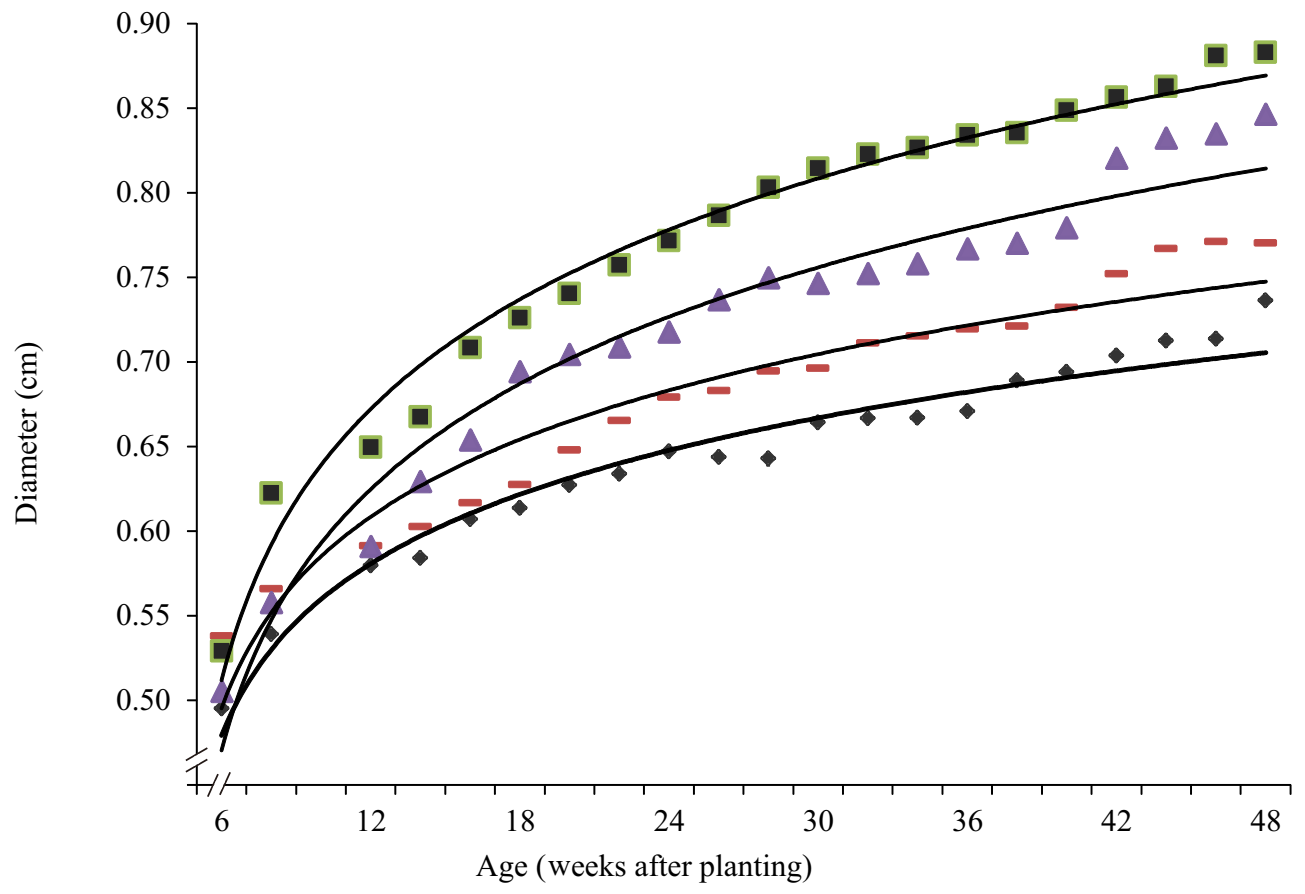

Figure 1 The diameter growth of 1 year seedlings of E. zwageri varieties. Exilis $(\diamond)$, ovoidus $(-)$, zwageri $(\boldsymbol{\square})$, grandis $(\Delta)$, $\log (-)$.

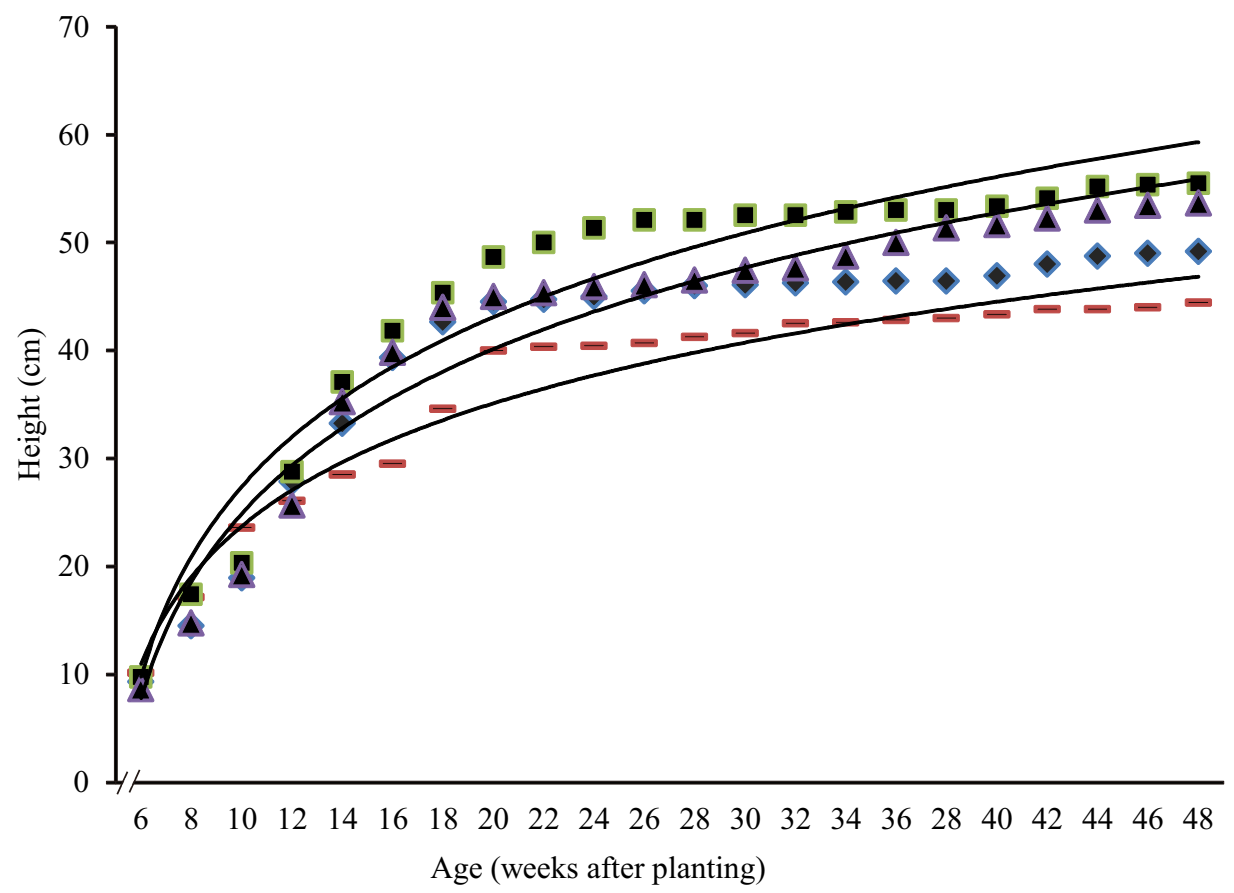

Figure 2 The height growth of 1 year seedlings of E. zwageri varieties. Exilis $(\boldsymbol{\nabla})$, ovoidus $(-)$, zwageri $(\boldsymbol{\square})$, grandis $(\Delta)$, $\log (\longrightarrow)$. 
significantly different from one another. Figures 1 and 2 show that zwageri variety had the best growth performance in stem diameter and height compared to other varieties. The differences among E. zwageri seedlings in shoot dry weight parameter were identical to the parameter of stem diameter.

The seed viability and seedling vitality of grandis variety seems to be the best among E. zwageri varieties; however, statistically it is not significantly different from zwageri variety. The results of this experiment do not fully support the statement that the bigger seeds have the bigger chance at life (Leishman et al. 2000; Turner 2001; Catovsky \& Bazzaz 2002). The seed weights of grandis and zwageri were significantly different from one another but their percentages of life seedlings were not significantly different. This result is parallel to Green (1999) who reported that larger seeds did not show higher and/or more rapid germination.

The growth rate of $E$. zwageri varieties seedlings is much slower compare to other tree species. Research conducted by Zahid et al. (2010) in arid environment show that the average height of 1-year-old Acacia, Albizzia, Azadirachta, and Eucalyptus was 115, 107, 55, and $200 \mathrm{~cm}$ against the average girth of plant at root collar, which was 34, 54, 19, and $62 \mathrm{~mm}$, respectively. Silviculturally, species with height gain of $>1$ $\mathrm{m}$ year $^{-1}$ and diameter increment $>1 \mathrm{~cm}$ year ${ }^{-1}$ are considered fast growing (Marcar et al. 1995). However, the biomass of one year E. zwageri seedlings is higher compare to Schima superba and Cryptocarya concinna (Mo et al. 2008).

The percentage of life seedlings of grandis was the highest compared to other varieties but its stem height and stem diameter were slightly lower than zwageri variety. This is also a proof that bigger seeds do not always provide better seedlings. As described by Green and Juniper (2004) despite a reserve effect favoring larger-seeded species, they performed no differently than smaller-seeded species in terms of their biomass allocation. However, the role of food storage in the seed is still strong to stimulate growth of seedlings. It can be seen from the growth rate among varieties that ovoidus and exilis are still the varieties that grew slower than the two other varieties (Figure 1 and Figure2). Many practitioners and local people also reported the dependence of $E$. zwageri seedlings on their food supply from the seeds. They reported that it is important to keep endosperm hanging on the seedling when transplanting is conducted, otherwise the seedlings will die even if they are big and mature enough.

These figures show that there is a strong correlation between age and diameter as well as age and height. Some researchers have reported that there is a positive and strong correlation between height and ages as well as between diameter and ages. This suggests that there is a great potential to increase volume gain per unit time by making selection based on height at an early age (Joyce et al. 2001; Xie \& Yanchuk 2002; Hardwood et al. 2002).

Stem diameter and height are good parameters to observe the effect of genetic factors on the phenotype of trees since some researchers found that both growth traits have a strong genetic basis (Blumenröther et al. 2001; Xie \& Yanchuk 2002). Additionally, Xie and Yanchuk (2002) found that site conditions had a greater effect on growth than on survival.
Since the experimental conditions are similar, therefore, the growth pattern of stem diameter and stem height of $E$. zwageri is strongly affected by genetic factors.

On shoot traits of white pine, Joyce et al. (2001) reported that significant differences in first year seedling height, initiation of shoot elongation, date of shoot growth cessation, length of shoot elongation periods, and the second year seedling height were detected among populations in the greenhouse. This result indicates that shoot traits have high value to observe the different growth performances of a tree species. The performance of shoot dry weight among E. zwageri varieties tends to be similar to stem diameter and height. This is understandable since shoot dry weight is a function of stem diameter and height. Since dry weight is more or less the net result of photosynthesis, it is no doubt that zwageri variety is able to grow better than other varieties.

Angle measurements on the first branch of E. zwageri seedlings obtained significantly different results among $E$. zwageri varieties (Table 1). The lowest value of branch angle belonged to zwageri variety. Based on Duncan multiple range test, it was significantly different from other varieties except grandis variety. Statistical analysis on number of branches showed that zwageri variety had more branches than the other varieties. It was significantly different from ovoidus and grandis varieties but not significantly different from exilis variety. Cluster analysis based on shoot traits shows ovoidus and exilis had the highest degree of similarity, followed by grandis variety. Zwageri was of out these clusters; however, it had a close relationship with grandis variety.

Branch formation is a result of the development of lateral buds along the stem. The formation of shoots and branches of trees is determined by the genetic make-up according to a precise pattern (Tomlinson 1978; Fisher 1986). The data of branch number shows that zwageri has the most amount of branches compared to other varieties.

The observation on angle between first branch and the stem of E. zwageri varieties revealed that zwageri variety had the smallest angle, followed by grandis, ovoidus and exilis varieties. This pattern of branch angle is parallel to the growth pattern of those varieties. There seems to be a relationship between the angle and the growth pattern, at least at seedling stage. The smaller branch angle gave a better growth rate.

This phenomenon is possibly due to specific characteristics of $E$. zwageri seedlings themselves. Since $E$. zwageri is a shade tolerant species especially at seedling stage, sunlight correlates negatively to its growth. The bigger branch angle leads to a more perpendicular position of leaves to the light. This condition is better for light-demanding species but it is not suitable for shade tolerant species. Ackerly and Bazzaz (1995) found that seedlings of both plagiotropic and orthotropic pioneer species (lightdemanding species) tend to orient their leaves perpendicular to diffuse light.

The counting results of leaf number show that zwageri had more leaves than other varieties; however, it was only significantly different from grandis,. The other varieties were not significantly different from each other. The length 
and width of leaves of one-year E. zwageri seedlings were significantly different among some varieties. Grandis had the longest and widest leaves. It was significantly different from ovoidus and exilis varieties in leaf width but only significantly different from ovoidus variety in leaflength.

Table 2 shows that petiole length and petiole ratio were not significantly different among all varieties. Numerically, zwageri had the longest petiole length while ovoidus had the shortest petiole length. Exilis had the highest value of petiole ratio while grandis had the lowest value of petiole ratio, but statistically these were not significantly different from one another.

The highest value of length:width ratio belonged zwageri variety and it was significantly different from grandis variety, which had the lowest value of length:width ratio. Grandis, ovoidus, and exilis varieties were not significantly different from one another. The results for total leaf area trait were slightly different from length:width ratio but zwageri variety still had the highest grade of total leaf area and it was significantly different from ovoidus. However, the other varieties were not significantly different from each other.

The amount of leaves and the total leaf area are two parameters that are closely related. The most important function of leaves is to conduct the photosynthesis process. During photosynthesis, leaves convert inorganic materials to organic compounds using energy from sunlight. Those organic compounds are the main sources of energy for organ development. The leaf parameter, especially total leaf area, is the most important parameter that influences photosynthesis (Ceulemans \& Saugier 1991; Hari et al. 1991). Then, the photosynthesis directly influences the growth rate of the seedling (Ledig \& Perry 1969).

Leaf length, leaf width and their ratio mostly affect the form of the leaf instead of its size; therefore, their role in the growth of E. zwageri seedlings is relatively lower than its leaf number and total leaf area. This phenomenon can be seen from the result of this experiment, in which those leaf traits did not have exact relationships with the growth rate of the seedlings. Leaf length tends to follow the trend that zwageri and grandis had better growth rates than did ovoidus and exilis. Leaf width and length:width ratio do not show parallel relationships with other parameters. However, leaf shape is an important characteristic to differentiate E. zwageri varieties which were obtained by observation from the field. Leaf length, width and leaf area are partially controlled by genetic factors as reported by Hovenden and Van der Schoor (2004) who conducted research in leaf morphology of southern beech (Nothofagus cunninghamii).

The root length of $E$. zwageri seedlings was significantly different among zwageri and exilis and ovoidus. Zwageri had the longest root length while ovoidus had the shortest. Even the length of grandis's root was shorter than zwageri's root, but they were not significantly different from each other. The results of root diameter measurement and analysis show that root diameter of $E$. zwageri seedlings were not significantly different among varieties. Numerically, zwageri had the biggest root diameter and exilis had the smallest root diameter, but they were statistically not different from each other (Table 3).

There are some root traits that significantly affected the ability of a root to uptake water and nutrients. Those traits are root length, root diameter, number of secondary roots, and root hairs. Since the root hairs were not measured in this experiment and the number of secondary roots and diameter were not significantly different, the main root trait that affected the growth of E. zwageri seedlings was root length. The longer the roots, the more water and nutrients they were able to uptake. As described by Bouma et al. (2001), ion transport capability is widely distributed over the root surface and is not restricted to the apical zones. Uptake capacity may be highest in the youngest part of the root axis.

However, the growth rate of roots themselves is also

Table 2 Mean values of leaf traits of 4 varieties of 1-year-old Eusideroxylon zwageri Teijsm. \& Binn. seedlings

\begin{tabular}{llllllll}
\hline \multicolumn{1}{c}{ Varieties } & $\begin{array}{c}\text { Amount of } \\
\text { leaves }\end{array}$ & \multicolumn{2}{c}{ Length $(\mathrm{cm})$} & Width $(\mathrm{cm})$ & $\begin{array}{c}\text { Petioles } \\
(\mathrm{cm})\end{array}$ & $\begin{array}{c}\text { Petiole } \\
\text { ratios }\end{array}$ & $\begin{array}{c}\text { Length: width } \\
\text { ratios }\end{array}$ \\
\hline Exilis & $30.67 \mathrm{ab}$ & $12.969 \mathrm{ab}$ & $5.632 \mathrm{a}$ & $0.784 \mathrm{a}$ & $0.058 \mathrm{a}$ & $2.318 \mathrm{ab}$ & $1,443.02 \mathrm{ab}$ \\
Ovoidus & $25.00 \mathrm{a}$ & $12.375 \mathrm{a}$ & $5.275 \mathrm{a}$ & $0.703 \mathrm{a}$ & $0.054 \mathrm{a}$ & $2.368 \mathrm{~b}$ & $1,083.41 \mathrm{a}$ \\
Zwageri & $37.50 \mathrm{~b}$ & $13.829 \mathrm{ab}$ & $5.889 \mathrm{ab}$ & $0.831 \mathrm{a}$ & $0.057 \mathrm{a}$ & $2.373 \mathrm{~b}$ & $2,114.65 \mathrm{~b}$ \\
Grandis & $21.50 \mathrm{a}$ & $14.114 \mathrm{~b}$ & $6.679 \mathrm{~b}$ & $0.791 \mathrm{a}$ & $0.053 \mathrm{a}$ & $2.114 \mathrm{a}$ & $1,724.70 \mathrm{ab}$ \\
\hline
\end{tabular}

The mean values that are followed by the same letters are not significantly different based on $5 \%$ significance level of Duncan multiple range test.

Table 3 Mean values of root traits of 4 varieties of 1-year-old Eusideroxylon zwageri Teijsm. \& Binn. seedlings

\begin{tabular}{llllc}
\hline Varieties & Lengths $(\mathrm{cm})$ & Diameters $(\mathrm{cm})$ & Dry weights $(\mathrm{g})$ & Amount of secondary root \\
\hline Exilis & $30.592 \mathrm{a}$ & $1.037 \mathrm{a}$ & $4.690 \mathrm{a}$ & $45.833 \mathrm{a}$ \\
Ovoidus & $28.400 \mathrm{a}$ & $1.090 \mathrm{a}$ & $5.215 \mathrm{a}$ & $53.833 \mathrm{a}$ \\
Zwageri & $38.852 \mathrm{~b}$ & $1.258 \mathrm{a}$ & $7.818 \mathrm{~b}$ & $59.833 \mathrm{a}$ \\
Grandis & $33.233 \mathrm{ab}$ & $1.197 \mathrm{a}$ & $7.223 \mathrm{ab}$ & $45.167 \mathrm{a}$ \\
\hline
\end{tabular}

The mean values that are followed by the same letters are not significantly different based on $5 \%$ significance level of Duncan multiple range test. 
affected by the activity of photosynthesis in the leaves, because energy for root development is supplied from the photosynthate, especially after the food reserves are exhausted. Therefore, in a very simple way, leaves and roots are closely related and dependent on each other. Roots are not able to grow in an optimum way if they are not supplied with enough photosynthate, while leaves can not conduct optimal photosynthesis activity if they are not supplied with enough water and nutrients by the roots (Kozlowski 1971; Thaler \& Pages 1996). Additionally, Drew and Ledig (1980) reported that new root growth might be particularly sensitive to current photosynthate supply. This fact is confirmed by the result of this experiment that zwageri variety that had the best leaf trait performance as well as the best root traits.

\section{Conclusion}

The result of research revealed that growth rate of $E$. zwageri seedlings is significantly different from one variety to another at most all of the growth parameters. Among the varieties, zwageri shows the best growth performance. It was indicated by the highest value of the stem diameter and height as well as shoot dry weight belongs to zwageri variety. The ability and vitality of this variety also explained why zwageri became the most dominant variety in the natural forest. Knowledge on the difference growth performance of $E$. zwageri varieties is very importance to understand not only for their management and silviculture practices but also for future researches.

\section{References}

Ackerly DD, Bazzaz FA. 1995. Seedling crown orientation and interception of diffuse radiation in tropical forest gaps. Ecology 76: 1134-1146. http://dx.doi.org/ $\underline{10.2307 / 1940921 .}$

Ashton PS. 1981. The need for information regarding tree age and growth in tropical forests. In: Bormann FH, Berlyn G, editors. Age and Growth Rate of Tropical Trees: New Directions for Research. New Haven: Yale University Press.

Beekman HAJM. 1949. Houtteelt in Indonesie (Silviculture in Indonesia). Publicate van de Stichting'Fonds Landbouw Exportbureaue`1916-1918. Wegeningen.

Bouma TJ et al. 2001. Estimating age-dependent costs and benefits of roots with contrasting life span: comparing apples and oranges. New Phytologist 150:685-695. http://dx.doi.org/10.1046/j.1469-8137.2001.00 $\underline{128 . x}$.

Blumenröther M, Bachmann M, Müller-Starck G. 2001. Genetic characters and diameter growth of provenances of scots pine (Pinus sylvestris L.). Silvae Genetica 50(56):212-222.

Catovsky S, Bazzaz FA. 2002. Feedback between canopy composition and seedling regeneration in mixed conifer broad-leaved forest. Oikos 98:403-420. http://dx. doi.org/10.1034/j.1600-0706.2002.980305.x.

Ceulemans RJ, Saugier B. 1991. Photosynthesis. In: Raghavendra AS, editor. Physiology of Tree. New York: John Wiley and Sons, Inc.

Drew AP, Ledig FT. 1980. Episodic growth and relative shoot: root balance in Loblolly pine seedlings. Annals of Botany 45:143-148.

Fisher JB. 1986. Branching Pattern and Angles in trees. In: Givnish TJ, editor. On the Economy of Plant Form and Function. Cambridge, UK: Cambridge University Press.

Gomez KA, Gomez AA. 1984. Statistical Procedures for Agricultural Research. New York: John Wiley and Sons, Inc.

Green PT. 1999. Seed germination in Chrysophyllum sp. nov., a large-seeded rainforest species in north Queensland: effects of seed size, litter depth and seed position. Australian Journal of Ecology 24(6):608-613. http://dx.doi.org/10.1046/j.1442-9993.1999.0099 4.x.

Green PT, Juniper PA. 2004. Seed-seedling allometry in tropical rain forest trees: seed mass-related patterns of resource allocation and the 'reserve effect. Journal of Ecology 92(3):397-408. http://dx.doi.org/10.1111 /j.0022-0477.2004.00889.x.

Hardwood CE, Lee DJ, Podberscek M. 2002. Genetic variation in early growth and stem form of Grevillea robusta in a provenance-family trial in south-eastern Queensland, Australia. Forest Genetics 9(1):55-61.

Hari P, Nikinmaa E, Korpilahti E. 1991. Modeling: canopy, photosynthesis and growth. In: Raghavendra AS, editor. Physiology of Tree. New York: John Wiley and Sons, Inc.

Hintze J. 2001. NCSS and PASS. Number Cruncher Statistical Systems. Kaysville, Utah. www.NCSS.com (September, 25th 2004).

Hovenden MJ, Van der Schoor JK. 2004. Nature vs nurture in the leaf morphology of Southern beech, Nothofagus cunninghamii (Nothofagaceae). New Phytologist 161(2):585-594. http://dx.doi.org/10.1046/j.14698137.2003.00931.x.

Irawan B, Gruber F. 2004. Morphological variability of ironwood (Eusideroxylon zwageri Teijsm.\& Binn.) in natural forests. Journal of Agriculture and Rural Development in the Tropics and Subtropics 80.

Irawan B. 2005. Ironwood (Eusideroxylon zwageri Teijsm. \& Binn.) and Its Varieties in Jambi, Indonesia. Göttingen: Cuvillier Verlag. 
Joyce DG, Lu P, Sinclair RW. 2001. Genetic variation in growth among populations of eastern White pine (Pinus strobus L.) in Ontario. Silvae Genetica 51 (4): 136-142.

Kiyono Y, Hastaniah 2000. Growth of Eusideroxylon zwageri seedlings and silvicultural changes in loggedover and burned forests of bukit Soeharto, East Kalimantan, Indonesia. Japan Agricultural Research Quarterly34(1)

Kostermans AJH. 1957. Lauraceae. Communication of the Forest Research Institute. Indonesia No. 57. Bogor: Balai Besar Penjelidikan Kehutanan.

Kostermans AJGH, Sunarno B, Martawijaya A, Sudo S. 1994. Eusideroxylon Teisjm. and Binnend. In: Soerianegara I, Lemmens RHMJ, editors. Plant Resources of South-East Asia 5 (1). Timber Trees: Major Commercial Timbers. Bogor: PROSEA.

Kozlowski TT. 1971. Growth and Development of Trees. New York and London: Academic Press.

Kurokawa H, Yoshida T, Nakamura T, Lai J, Nakashizuka T. 2003. The age of tropical rain-forest canopy species, Borneo ironwood (Eusideroxylon zwageri), determined by ${ }^{14} \mathrm{C}$ dating. Journal of Tropical Ecology 19:1-7. http://dx.doi.org/10.1017/S0266467403003018.

Ledig FT, Perry TO. 1969. Net assimilation rate and growth in Loblolly pine seedlings. Forest Science 15: 431-438.

Leishman MR,Wright IJ, Moles AT,Westoby M. 2000. The evolutionary ecology of seed size. In: Fenner M, editor. Seeds-the Ecology of Regeneration in Plant Communities 2ndedition. CABI publishing. http://dx. doi.org/10.1079/9780851994321.0031.

Marcar ND et al. 1995. Trees for Saltland: A Guide to Selecting Native Species for Australia. Canberra: Division of Forestry, CSIRO.
Mo J, Li D, Gundersen P. 2008. Seedling growth response of two tropical tree species to nitrogen deposition in southern China. European Journal of Forest Research 127(4): 275-283. http://dx.doi.org/10.1007/s10342008-0203-0.

Oldfield S, Lusty C, Kinven AM. 1998. The World List of Threatened Trees. Cambridge: World Conservation Press.

Thaler P, Pages L. 1996. Root apical diameter and root elongation rate of rubber seedlings (Hevea brasiliensis) show parallel responses to photoassimilate availability. Physiologia Plantarum 97:365-371. http://dx.doi. org/10.1034/j.1399-3054.1996.970222.x.

Tomlinson PB. 1978. Branching and axis differentiation in tropical trees. In: Tomlinson, PB, Zimmerman, MH, editors. Tropical Trees as Living Systems. New York: Cambridge University Press.

Turner IM. 2001. The Ecological of Trees in the Tropical Rain Forest. Cambridge Tropical Biology Series. New York: Cambridge University Press. http://dx.doi.org/ 10.1017/CBO9780511542206.

Tuyt P. 1939. Schaduwrijen cultuur van ijzerhout in de residente Palembang (Strip planting of ironwood). Tectona. DI.XXXII: 805-827.

Weidelt HJ. 1997. Tropical silviculture. Göettingen: Faculty of Forestry and Ecology, Göttingen University.

Xie CY, Yanchuk AD. 2002. Genetic parameters of height and diameter of interior spruce in British Columbia. Forest Genetics 9(1):1-10.

Zahid DM, Shah FUR, Majeed A. 2010. Planting Eucalyptus cammaldulensis in arid environment - Is it useful species under water deficit system? Pakistan Journal of Botany 42(3): 1733-1744. 